\title{
Occurrence of 23-epi-26-deoxyactein and Cimiracemoside $A$ in Various Black Cohosh Tissues Throughout the Growing Season
}

\author{
Andrew L. Thomas ${ }^{1}$ and Richard J. Crawford, Jr. \\ Southwest Research Center, University of Missouri-Columbia, Mt. Vernon, \\ MO 65712
}

\author{
George E. Rottinghaus and John K. Tracy \\ Veterinary Medical Diagnostic Laboratory, University of Missouri- \\ Columbia, Columbia, MO 65211
}
Wendy L. Applequist, Besa E. Schweitzer, Larry J. Havermann, Scott F. Woodbury, and James S. Miller
Missouri Botanical Garden, St. Louis, MO 63166

Mark R. Ellersieck

Agricultural Experiment Station, University of Missouri-Columbia, Columbia, MO 65211

Dean E. Gray

Midwest Research Institute, Kansas City, MO 64110

Additional index words. botanical, medicinal herb, menopause, 27-deoxyactein, Actaea, Cimicifuga

\begin{abstract}
Black cohosh [Actaea racemosa L.; Cimicifuga racemosa (L.) Nutt.] is a perennial herb native to North America that is commonly used for the treatment of menopausal symptoms. The plant is almost exclusively harvested from the wild and is being threatened by overharvesting in some regions. As demand for this plant continues to increase, the potential for profitable cultivation of this species is becoming realistic. Little is known about the effect of various cultivation practices, soils, environments, and harvest times on the multitude of phytochemicals that occur in black cohosh. Furthermore, although the rhizome is the organ that is traditionally consumed, other tissues also contain various quantities of important phytochemicals, but this has not been well documented. The objectives of this study, therefore, were to ascertain any environmental effects on the production of two representative phytochemicals (23-epi-26-deoxyactein and cimiracemoside $A$ ) and to elucidate any season-long patterns or variations in the production of these compounds within five black cohosh tissues (leaf, rachis, rhizome, root, and inflorescence). All black cohosh tissues contained 23-epi-26-deoxyactein with substantially more, as a percentage of dry weight, detected in inflorescence $\left(28,582\right.$ to $\left.41,354 \mathrm{mg} \cdot \mathrm{kg}^{-1}\right)$ and leaf $(8250$ to $16,799 \mathrm{mg} \cdot \mathrm{kg}^{-1}$ ) compared with rhizome (2688 to $\left.4094 \mathrm{mg} \cdot \mathrm{kg}^{-1}\right)$, and all tissues experienced a linear season-long decrease in occurrence of this compound. Cimiracemoside A was not detected in leaf tissues. The highest levels were found in rhizome (677 to 1138 $\mathrm{mg} \cdot \mathrm{kg}^{-1}$ ) and root (598 to $\left.1281 \mathrm{mg} \cdot \mathrm{kg}^{-1}\right)$, which likewise experienced a significant seasonlong decrease in this compound, whereas levels in the rachis $\left(0\right.$ to $\left.462 \mathrm{mg} \cdot \mathrm{kg}^{-1}\right)$ increased over time. In general, environmental factors did not affect production of either compound. Varying seasonal patterns in phytochemical production, combined with differences in phytochemical content among plant tissues, point to the potential for more targeted horticultural production of these and other medicinal compounds within black cohosh.
\end{abstract}

\footnotetext{
Received for publication 18 Dec. 2006. Accepted for publication $24 \mathrm{Feb} .2007$.

This publication was made possible by grant no. DHHS 5 PO1-ES 10535 (Dennis Lubahn, PI) from the National Institute of Environmental Health Sciences (NIEHS) and the National Center for Complementary and Alternative Medicine (NCCAM); its contents are solely the responsibility of the authors and do not necessarily represent the official views of the NIEHS/NCCAM, NIH.

${ }^{1}$ To whom reprint requests should be addressed; e-mail thomasal@missouri.edu
}

Black cohosh (Actaea racemosa L., Ranunculaceae) is an attractive perennial herb native to the midwestern and eastern United States. It is commonly known as Cimicifuga racemosa (L.) Nutt., but genetic data have shown that the genera Actaea and Cimicifuga should be combined (Compton et al., 1998). Black cohosh is generally found growing in rich, fertile, well-drained soils as an understory plant in deciduous forests. It has become a popular dietary supplement in recent years with consumer demand increasing in North America and Europe. The rhizome has been used historically to stimulate menstruation, to promote lactation, to help babies sleep, and to treat rheumatic pains, coughs, colds, kidney trouble, and constipation (Moerman, 1998). Presently, extracts of the rhizome and roots are approved in Germany for treating premenstrual discomfort and menopausal ailments, and are commonly used as dietary supplements by North American women to replace or supplement estrogen treatments in hormone replacement therapy. Black cohosh has been shown to reduce menopausal hot flashes in multiple human clinical trials (Düker et al., 1991; Lehmann-Willenbrock and Riedel, 1988; McKenna et al., 2001; Pethö, 1987) and is therefore in great and growing demand (Blumenthal, 1999, 2002). As recent publicity regarding the adverse effects of hormone replacement therapy has inspired greater interest in putatively safe herbal alternatives, consumption of black cohosh is likely to continue to increase.

The phytochemical content of black cohosh is complex and still inadequately understood; the a.i. and mechanisms of action are not known. Most attention has focused on triterpenoids, which include such compounds as actein, 23-epi-26-deoxyactein (previously but incorrectly termed 27-deoxyactein; Chen et al., 2002a), cimiracemosides, and cimicifugosides. These encompass a substantial suite of related compounds in Actaea species; for example, Chen et al. (2002b) isolated eight known and 13 novel triterpene glycosides from $A$. racemosa. Compounds in this class have shown a variety of in vitro activities, including inhibition of breast cancer cells (Einbond et al., 2004) and anti-HIV activity (Sakurai et al., 2004). However, several other potentially bioactive compound classes are also present in black cohosh, including caffeic and cinnamic acid derivatives and related compounds ( $\mathrm{Li}$ et al., 2003) and phenylpropanoid esters called cimiracemates (Chen et al., 2002c). A commercial black cohosh product has been reported to contain the phytoestrogenic isoflavone formononetin (Jarry et al., 1985), which was presumed by some to be an a.i. or even the only a.i. One study (Panossian et al., 2004), using thin-layer chromatography-fluorometry, purportedly found minute quantities, but other studies of black cohosh rhizomes and products have not found formononetin (Jiang et al., 2006a, 2006b; Kennelly et al., 2002; Li et al., 2002; Struck et al., 1997). Furthermore, a number of in vitro and animal studies (Burdette et al., 2003; Einbond et al., 2004; Liu et al., 2001) have found no significant effects consistent with a primarily estrogenic activity.

Nearly all black cohosh material is presently harvested from the wild, and commercial cultivation of this species is rare in North America (Persons and Davis, 2005). The growing demand for black cohosh products, coupled with the potential threat of overharvesting of native populations, points to an 
excellent horticultural potential for this species. Although some guidelines for the cultivation of black cohosh have been published (Cech, 2002; Persons and Davis, 2005), little research has been conducted to determine ideal cultivation methods for this species, which, like many woodland perennials, will not thrive if conditions are not suitable. For example, plants cultivated in heavy soil in wet years have proven to be highly susceptible to a variety of fungal diseases (Abad et al., 2005; Thomas et al., 2006). Also, potential influences of cultivation methodologies on phytochemical content have not been thoroughly explored. In one black cohosh study, McCoy et al. (2007) found no differences in triterpene glycoside production, as a percentage of dry weight, in plants cultivated within three different environments (managed agricultural shadehouse, forest, or disturbed forest edge). In other species, however, it has been shown that environmental conditions can have a significant impact on phytochemical content (e.g., Hornok, 1986; Mudge et al., 2004).

Another question is when should plants be harvested to maximize phytochemical yield; the concentration of a.i. in a medicinal plant, as a percentage of dry weight, may be relatively constant throughout the growing season (e.g., Rushing et al., 2004) or may display significant temporal variation (e.g., Sen and Datta, 1986). Although black cohosh is traditionally harvested in the fall, Popp et al. (2002) reported that triterpene glycosides and isoferulic acid increased in mid-May and June in black cohosh cultivated in Germany. Additionally, there is the question of which plant tissues might yield maximum quantities of desirable phytochemicals. The use of renewable aboveground tissues such as leaves in place of roots or rhizomes that are at risk of unsustainable wild collection has been explored or suggested for some threatened species such as ginseng (Popovich and Kitts, 2004; Xie et al., 2004). To date, there has been little inquiry into chemical content of plant tissues other than those traditionally used for black cohosh or many other important root crops. Our objective for the present study, therefore, was to quantify any seasonal patterns or variations in the content of two representative bioactive triterpenoids (23-epi-26-deoxyactein and cimiracemoside A) within black cohosh leaf, rachis, rhizome, root, and inflorescence tissues across multiple environments.

\section{Materials and Methods}

The study was conducted at two geographically different sites in Missouri that are $304 \mathrm{~km}$ apart: the University of MissouriColumbia's Southwest Research Center near Mt. Vernon in southwest Missouri (lat. $37^{\circ} 4^{\prime} \mathrm{N}$, long. $93^{\circ} 53^{\prime} \mathrm{W}$, alt. $378 \mathrm{~m}$ ) and the Shaw Nature Reserve of Missouri Botanical Garden at Gray Summit in east-central Missouri (lat. $38^{\circ} 28^{\prime} \mathrm{N}$, long. $90^{\circ} 49^{\prime} \mathrm{W}$, alt. 174 to $188 \mathrm{~m}$ ). Both of these sites are at the northern edge of the natural range of black cohosh in Missouri (Steyermark, 1977).
At Mt. Vernon, black cohosh rhizomes were transplanted into five proximate locations within a 0.5 -ha area on varying slopes, aspects, and soils in a natural, undisturbed dry-mesic oak-hickory (Quercus-Carya) forest. Indigenous populations of black cohosh were not found in the vicinity of these plantings; however, the species is occasionally found in the region. The soils at this site consisted of a Waben-Cedargap cherty silt loam complex (Hughes, 1982). The Waben cherty silt loam (loamy-skeletal, siliceous, mesic Ultic Hapludalfs) is a deep, nearly level to gently sloping, well-drained soil on narrow terraces and footslopes with moderately rapid water permeability and medium surface runoff, whereas the Cedargap cherty silt loam (loamy-skeletal, mixed, mesic Cumulic Hapludolls) is a nearly level, somewhat excessively drained soil on narrow flood plains with moderately rapid permeability and slow surface runoff. Both have a low water-holding capacity (Hughes, 1982). Soil fertility tests indicated $\mathrm{pH} 5.0$, organic matter $3.6 \%$, cation exchange capacity $10.4 \mathrm{meq} /$ $100 \mathrm{~g}$, low levels of $\mathrm{P}$ and $\mathrm{K}$, and adequate levels of $\mathrm{Ca}$ and $\mathrm{Mg}$ based on recommendations for vegetable production.

At Gray Summit, rhizomes were transplanted into two locations $300 \mathrm{~m}$ apart on east to southeast-facing $5 \%$ slopes within a mature, mesic, oak-hickory forest. Native populations of black cohosh were likewise not found in the vicinity of this planting; however, a population of a related species, Actaea pachypoda Ell., which prefers a similar habitat to black cohosh, occurred within $0.5 \mathrm{~km}$ of the study site. The soil was a Haymond silt loam (coarse-silty, mixed, nonacid, mesic Typic Udifluvents), which is a deep to very deep, gently sloping to steep, well-drained, silty soil on uplands (Held, 1989). A soil test indicated $\mathrm{pH} 4.8$, organic matter $2.1 \%$, cation exchange capacity $12.3 \mathrm{meq} / 100 \mathrm{~g}$, very low P levels, low $\mathrm{Ca}$ levels, and adequate levels of $\mathrm{K}$ and $\mathrm{Mg}$.

The black cohosh plant material for these experiments was acquired from Elixir Farm Botanicals, Brixey, Mo., who originally obtained propagules from wild plants occurring in the surrounding Ozark forests. These materials were vouchered and confirmed to be Actaea racemosa L. [A. Thomas 35, 36, 37 (MO)]. More than 350 large, robust, mature black cohosh rhizomes were inspected, sorted, and then randomly assigned to the two sites. The 175 rhizomes per site were randomized before transplantation on 7-8 Nov. 2002 at Mt. Vernon and 9 Oct. 2002 at Gray Summit. Spacing was arbitrary and widespread (minimum $1 \mathrm{~m}$ apart) in an attempt to simulate somewhat naturally occurring populations of the species. The plants were not irrigated or fertilized, and no pesticides were used.

Harvest of entire black cohosh plants at both sites began soon after leaf emergence in spring (14 May 2003, 6 May 2004) and continued every 2 weeks throughout the season until leaf senescence (1 Oct. 2003, 23 Sept. 2004). This yielded 11 season-long tissue samplings from two disparate sites over 2 years for laboratory analysis. For each harvest, six random plants per site were dug and then dissected into leaf, rachis (commonly referred to as stem), rhizome, root, and inflorescence (in season). Fresh and dry weights of these separated plant tissues were determined for large numbers of individual plants. To obtain enough dry weight tissue for analysis, the separated tissues from each of the six plants per harvest were combined. Samples were then washed clean of all soil and foreign matter, chopped into small pieces, frozen in a standard $\left(-17^{\circ} \mathrm{C}\right)$ freezer, then later freeze-dried and ground into a fine powder (35 mesh) with a Udy cyclone mill (Udy Corp., Fort Collins, Colo.).

A total of 44 bulked six-plant samples each for leaf, rachis, rhizome, and root, and 10 samples of inflorescence (186 total samples) were prepared and analyzed by highperformance liquid chromatography (HPLC) with evaporative light scattering detection (ELSD). Samples were analyzed at the conclusion of each of the two growing seasons, and all HPLC standards were calibrated to the original standards. Our methods were modified from Li et al. (2002) and used a gradient mobile phase recommended by ChromaDex (Santa Ana, Calif.). Ground black cohosh tissue samples $(0.5 \mathrm{~g})$ were weighed into 50-ml Falcon Tubes (Fisher Scientific, Pittsburgh), $20 \mathrm{~mL}$ methanol : water (80:20) was added, and the tubes placed in a sonicator waterbath at $55{ }^{\circ} \mathrm{C}$ for $3 \mathrm{~d}$ with occasional shaking. The tubes were centrifuged and an aliquot removed for analysis. The HPLC system consisted of a Hitachi L-7100 (Hitachi, Ltd., Tokyo) pump with gradient flow at $1.0 \mathrm{~mL} / \mathrm{min}$; a Hitachi L-7200 autosampler (20- $\mu 1$ injection); and an ELSD Model 301 (ESA, Chelmsford, Mass.) with a Prodigy, $5 \mu \mathrm{m}, \mathrm{C} 18,250 \times 4.6 \mathrm{~mm}$ reversed-phase analytical column fitted with a SecurityGuard C18 (ODS) $4.0 \times 3.0 \mathrm{~mm}$ guard column (Phenomenex, Torrance, Calif.). The ELSD detector had the evaporation temperature set at $50{ }^{\circ} \mathrm{C}$ and the nebulizer temperature set at $35{ }^{\circ} \mathrm{C}$ with the photomultiplier tube set at $850 \mathrm{~V}$. The chromatographic gradient solvent system included $\mathrm{H}_{2} \mathrm{O}$, acetonitrile (ACN), and EtOH. The mobile phase was: 0 min, $56 \%$ $\mathrm{H}_{2} \mathrm{O}, 21 \%$ ACN, 23\% EtOH; $35 \mathrm{~min}, 52 \%$ $\mathrm{H}_{2} \mathrm{O}, 14 \%$ ACN, 34\% EtOH; 36 min, 56\% $\mathrm{H}_{2} \mathrm{O}, 21 \% \mathrm{ACN}, 23 \% \mathrm{EtOH}$; and $50 \mathrm{~min}$, $56 \% \mathrm{H}_{2} \mathrm{O}, 21 \% \mathrm{ACN}, 23 \%$ EtOH. Primary standards $\left(500 \mathrm{mg} \cdot \mathrm{kg}^{-1}\right)$ of 23-epi-26-deoxyactein and cimiracemoside A (ChromaDex) were prepared in $80 \% \mathrm{ACN}: \mathrm{H}_{2} \mathrm{O}$. Working standards of 250,125 , and $62.5 \mathrm{mg} \cdot \mathrm{kg}^{-1}$ were then prepared in $80 \% \mathrm{ACN}: \mathrm{H}_{2} \mathrm{O}$. The retention times were $17.45 \mathrm{~min}$ for cimiracemoside A and $29.17 \mathrm{~min}$ for 23-epi-26deoxyactein. Data were recorded and processed by a Hitachi D-7000 data acquisition package with ConcertChrom software on a microcomputer. The presence of 23-epi-26deoxyactein was further confirmed with additional MS parameters initially derived from He et al. (2000). This system used a Quattro LC mass spectrometer (Micromass, Beverly, 
Mass.) with Micromass MassLynx data system (version 3.4) set to positive atmospheric pressure chemical ionization mode with 100 to 1000 amu mass range scanned, $150{ }^{\circ} \mathrm{C}$ source temperature, $450^{\circ} \mathrm{C}$ desolvation temperature, cone voltage $75 \mathrm{~V}$, and scan time $1 \mathrm{~s}$.

An analysis of variance was conducted using the SAS GLM procedure (SAS Institute, Cary, N.C.) to elucidate differences in the quantities of the two phytochemicals among tissues, between years and sites, and across the growing season. Initial analyses revealed no significant differences in the production of 23-epi-26-deoxyactein and cimiracemoside A between the 2 years and between the two sites (data not shown). Therefore, the data were combined and analyzed as a randomized complete block design using year and site as blocks $(n=4)$. There were 8 days' difference in numbered harvests (1 to 11) between the 2 years, but the initial harvest each year was based on physiological stage of plant emergence in spring (primarily affected by weather conditions) rather than a strict calendar date. Therefore, the first through 11th harvests in both years were individually pooled for statistical determination of any season-long trends. To confirm or define any seasonal trends in occurrence of the two phytochemicals, polynomial orthogonal contrasts were performed to test for significant linear, quadratic, or cubic trends across the growing season. Mean separation was determined by Duncan's multiple range test with differences considered significant at the $P \leq 0.05$ level.

\section{Results and Discussion}

The black cohosh transplants emerged and thrived at both locations with little care. In 2006, 4 years after the initial planting, the remaining unharvested plants continued to flourish at both locations, indicating that the sites selected were satisfactory for ordinary growth and survival of black cohosh. Figure 1 provides detail on the season-long occurrence of 23-epi-26-deoxyactein within the five black cohosh tissues during the study. All data are based on dry plant tissue weight. Root and rachis samples generally contained similar amounts of 23-epi-26-deoxyactein with means ranging from 1149 to $1970 \mathrm{mg} \cdot \mathrm{kg}^{-1}$ (root) and 598 to $1987 \mathrm{mg} \cdot \mathrm{kg}^{-1}$ (rachis). Rhizomes had mean levels ranging from 2688 to $4094 \mathrm{mg} \cdot \mathrm{kg}^{-1}$, and leaves much more at 8250 to $16,799 \mathrm{mg} \cdot \mathrm{kg}^{-1}$. Inflorescences contained roughly 10 times the amount of 23-epi-26-deoxyactein as a percentage of dry weight compared with rhizomes with mean levels ranging from 28,582 to $41,354 \mathrm{mg} \cdot \mathrm{kg}^{-1}$. Statistically significant season-long decreasing linear trends in occurrence of 23-epi-26deoxyactein were detected in all five plant tissues (Fig. 1).

No detectable amount of cimiracemoside A was found in any leaf sample, whereas varying amounts were detected in other tissues (Fig. 2). In general, more cimiracemoside A was detected in rhizome and root tissues compared with inflorescence and
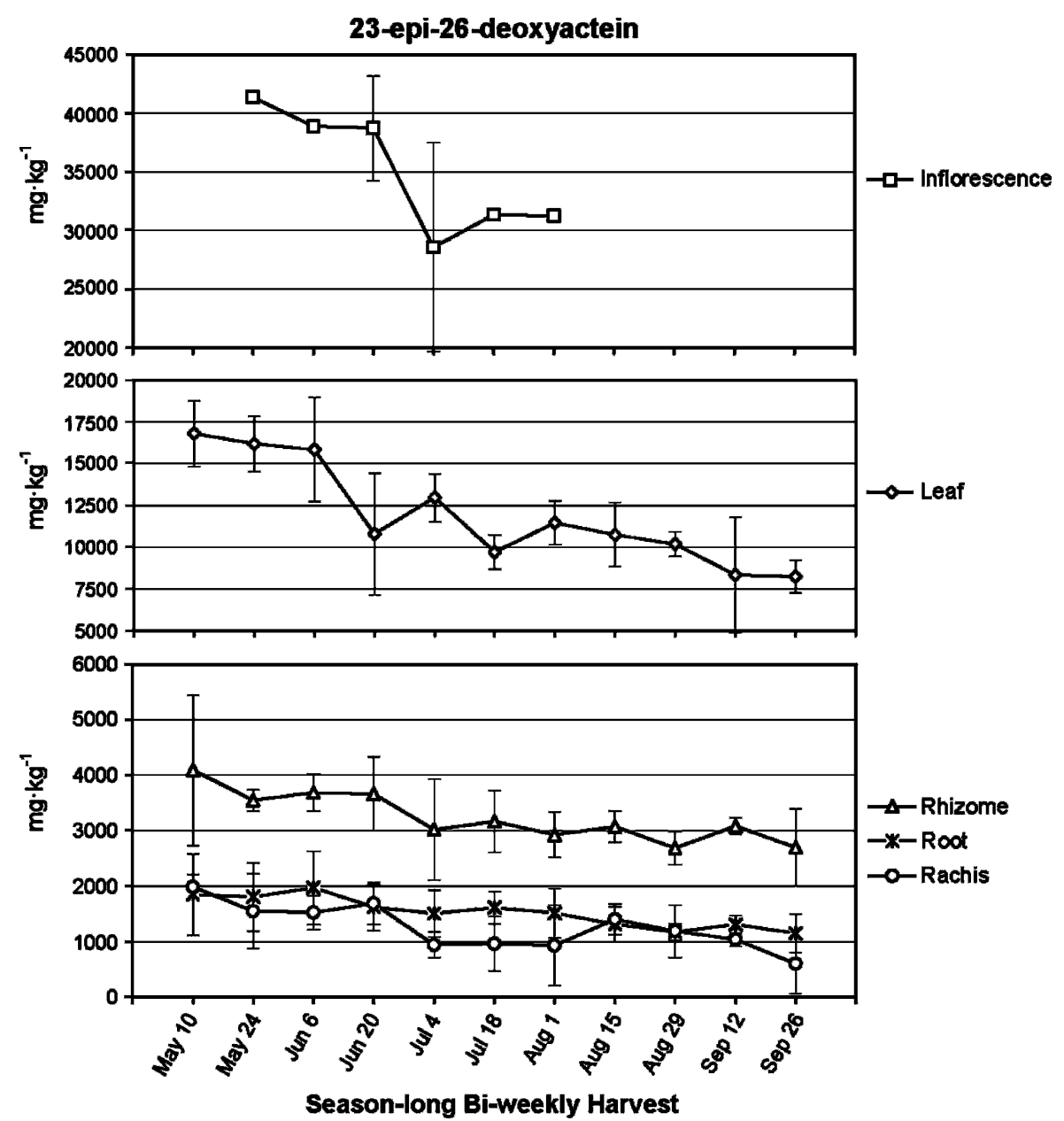

Fig. 1. Mean yields $\left(\mathrm{mg} \cdot \mathrm{kg}^{-1}\right) \pm \mathrm{SD}$ of 23-epi-26-deoxyactein harvested biweekly across two growing seasons at two Missouri locations $(n=4)$ within five black cohosh tissues. The dates shown are an average of the biweekly harvest dates over two seasons. Vertical bars represent sDs. Linear season-long biweekly decreases $\left(\mathrm{mg} \cdot \mathrm{kg}^{-1}\right)$ in 23-epi-26-deoxyactein were as follows: inflorescence -2474 ; leaf -852 ; rhizome -122 ; root -77 ; and rachis -98 . Linear season-long decreases were significant $(P \leq$ 0.05 ) for all tissues.

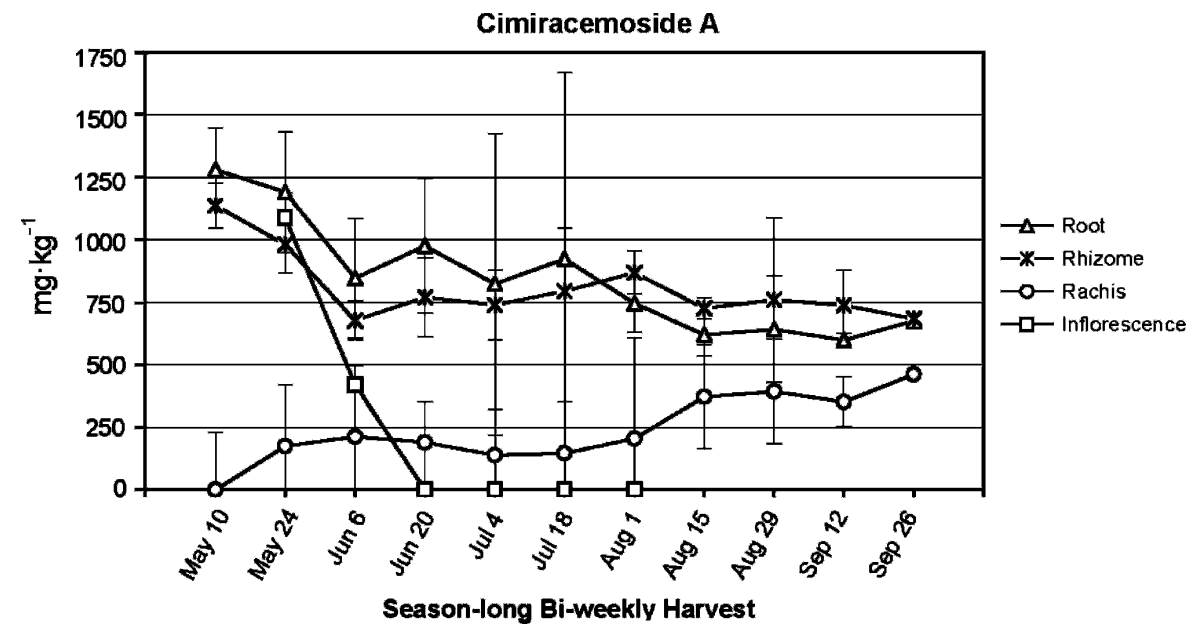

Fig. 2. Mean yields $\left(\mathrm{mg} \cdot \mathrm{kg}^{-1}\right) \pm \mathrm{SD}$ of cimiracemoside A harvested biweekly across two growing seasons at two Missouri locations $(n=4)$ within four black cohosh tissues. The dates shown are an average of the biweekly harvest dates over two seasons. Vertical bars represent SDs. Linear season-long biweekly decreases were significant for root and rhizome, whereas a significant increase was detected for rachis $(P \leq 0.05)$. Season-long biweekly changes $\left(\mathrm{mg} \cdot \mathrm{kg}^{-1}\right)$ in cimiracemoside A were as follows: rhizome -28 ; root -64 ; and rachis +36 . No cimiracemoside A was detected in any leaf sample. Although statistically significant, the mean biweekly change figure for inflorescence is not presented because of multiple readings below detection limits. 
rachis. Mean levels of this compound ranged from 677 to $1138 \mathrm{mg} \cdot \mathrm{kg}^{-1}$ in rhizome, 598 to $1281 \mathrm{mg} \cdot \mathrm{kg}^{-1}$ in root, and 0 to $462 \mathrm{mg} \cdot \mathrm{kg}^{-1}$ in rachis. The initial mean inflorescence sampling $\left(1089 \mathrm{mg} \cdot \mathrm{kg}^{-1}\right)$ was similar to root and rhizome samples on that date, but levels thereafter quickly declined to below detection limits as the flowering season progressed. Interestingly, although cimiracemoside A was not found in leaf tissues, it was found in significantly increasing levels in rachis tissues across the season, whereas, at the same time, levels in rhizome and root tissues significantly decreased (Fig. 2).

Because no significant differences were detected across the two sites or the 2 years with either compound, the production and accumulation of both 23-epi-26-deoxyactein and cimiracemoside $\mathrm{A}$ do not appear to be strongly dependent on environmental circumstances. However, significant season-long differences in phytochemical production, combined with differences in content among various plant tissues, suggest that horticultural refinement in the production and harvest of these and other plant compounds may be possible. Because both compounds in all tissues (except cimiracemoside $\mathrm{A}$ in rachis) tended to be present at the highest levels soon after emergence in spring and thereafter declined across the season, we might speculate that the increase in physiological activity associated with the spring awakening and emergence of the plant stimulates the production of high levels of these compounds. Our results, however, do not permit us to satisfactorily speculate as to whether specific plant tissues (as opposed to several or all tissues) produce such compounds nor if such compounds may be translocated throughout the plant for some purpose.

With traditional harvest of cultivated black cohosh rhizome, plants are usually grown for 3 to 5 years before being destructively harvested (Persons and Davis, 2005). If leaves and inflorescences could be used as sources of active compounds, destructive harvest of plants (cultivated or wild) may not be necessary, repetitive annual harvest could be established, and horticultural techniques could possibly be optimized for production of large quantities of inflorescences and leaves. However, the producer must consider the relative amount of a particular phytochemical produced within a specific tissue compared with the total dry matter yield of that and other tissues. Table 1 provides mean fresh and dry weight yields of the various tissues from large numbers of individual black cohosh plants that we harvested. As an example, although inflorescence tissues produced roughly 10 times the amount of 23-epi-26-deoxyactein compared with rhizome (Fig. 1), the dry matter production of inflorescence tissues per plant ( $2.7 \mathrm{~g}$ ) was only one-fourth the dry matter production of rhizome $(10.9 \mathrm{~g})$.

It is common for different plant tissues to have different phytochemical profiles as was seen in this study. In plants containing suites of numerous related bioactive compounds, the activity is likely attributable to the sum

Table 1. Mean single plant fresh and dry weight yield from five harvested black cohosh tissues at two Missouri locations during 2003 and 2004.

\begin{tabular}{|c|c|c|c|c|c|}
\hline & Rhizome & Root & Leaf & Rachis & Inflorescence \\
\hline Number of samples & 147 & 117 & 117 & 117 & 27 \\
\hline $\begin{array}{l}\text { Mean per plant fresh } \\
\text { weight }(\mathrm{g})\end{array}$ & $35.1 \pm 10.8^{z}$ & $12.6 \pm 7.0$ & $21.0 \pm 19.4$ & $15.3 \pm 14.6$ & $12.4 \pm 4.5$ \\
\hline $\begin{array}{l}\text { Mean percent moisture } \\
\text { in fresh tissues } \\
\text { Mean }\end{array}$ & $69 \%$ & $55 \%$ & $74 \%$ & $80 \%$ & $77 \%$ \\
\hline $\begin{array}{l}\text { Mean per plant dry } \\
\text { weight }(\mathrm{g})\end{array}$ & 10.9 & 5.7 & 5.4 & 3.1 & 2.7 \\
\hline
\end{tabular}

${ }^{\mathrm{z}}$ Value $\pm \mathrm{SD}$.

of the individual effects of many or all of these components, plus any synergistic or antagonistic effects, rather than to a few compounds alone. This study found high levels of two bioactive triterpenoids, selected as examples, in aboveground tissues; however, that does not demonstrate that the probably dozens of other bioactive triterpenoids from the rhizome, nor members of other compound classes such as caffeic and cinnamic acid derivatives, are likewise present in adequate quantity. More seriously, although black cohosh as traditionally used is well tolerated, Lloyd and Lloyd (1884) reported that the foliage is somewhat toxic, causing nausea and a burning sensation when consumed. It would therefore be premature to consider alleviating threats to wild black cohosh populations by harvesting renewable, nontraditionally used plant parts, but if further biomedical research identifies primary a.i. with certainty, the potential exists for producing highly standardized, pharmaceutical-like products from active compounds in black cohosh leaves and inflorescences.

Traditionally, collection or harvest of most rhizome and root crops occurs in autumn, toward the end of a growing season, at which time phytochemical content is often presumed to be highest. Indications from this study, as well as from Popp et al. (2002), are that this is not the case with black cohosh. Phytochemical concentrations of the two compounds in this study decreased over the course of the growing season in most tissues. More potent black cohosh products might therefore be readily produced by harvesting cultivated material earlier in the season. If leaves and inflorescences were determined to be useful for the production of 23-epi-26deoxyactein and cimiracemoside A, along with other phytochemicals that behave similarly in the plant, harvest early in the season would seem to be clearly preferable. Potential harm to these perennial plants incited by removing newly flushed leaves in spring after overwintered carbohydrate reserves have been largely depleted would have to be considered. Additional research would be merited to determine whether secondary flushes of leaves and inflorescences would be produced and if they would contain similarly high concentrations of phytochemicals. The concept of a repeated harvest of emerging foliage until plants begin to show signs of carbohydrate depletion, as is done with the vegetable asparagus (Asparagus officinalis L.), might also be investigated.
As the horticultural and medicinal knowledge of black cohosh cultivation is gradually elucidated and accumulated, and as specific phytochemicals within black cohosh tissues are individually evaluated clinically for efficacy in treating menopausal and other healthrelated concerns, the cultivation of black cohosh (as well as other medicinals) will likely and necessarily become more focused toward very specific phytochemical production goals. The results of this study suggest that black cohosh is well suited for this type of horticultural development.

\section{Literature Cited}

Abad, Z.G., J. Phillips, and A.L. Thomas. 2005. Black root and crown rot of black cohosh (Actaea racemosa L.) is associated to Phytophthora and Pythium species. Phytopathology 95:S1.

Blumenthal, M. 1999. Herb market levels after five years of boom: 1999 sales in mainstream market up only $11 \%$ in first half of 1999 after $55 \%$ increase in 1998. HerbalGram 47:64-65.

Blumenthal, M. 2002. Herb sales down in mainstream market, up in natural food stores. HerbalGram 55:60.

Burdette, J.E., J. Liu, S.N. Chen, D.S. Fabricant, C.E. Piersen, E.L. Barker, J.M. Pezzuto, A. Mesecar, R.B. van Breemen, N.R. Farnsworth, and J.L. Bolton. 2003. Black cohosh acts as a mixed competitive ligand and partial agonist of the serotonin receptor. J. Agr. Food Chem. 51:5661-5670.

Cech, R. 2002. Growing at-risk medicinal herbs. Horizon Herbs, LLC, Williams, Ore.

Chen, S.N., W. Li, D.S. Fabricant, B.D. Santarsiero, A. Mesecar, J.F. Fitzloff, H.H. Fong, and N.R. Farnsworth. 2002a. Isolation, structure elucidation, and absolute configuration of 26deoxyactein from Cimicifuga racemosa and clarification of nomenclature associated with 27-deoxyactein. J. Nat. Prod. 65:601-605.

Chen, S.N., D.S. Fabricant, Z.Z. Lu, H.H. Fong, and N.R. Farnsworth. 2002b. Cimiracemosides I-P, new 9,19-cyclolanostane triterpene glycosides from Cimicifuga racemosa. J. Nat. Prod. 65:1391-1397.

Chen, S.N., D.S. Fabricant, Z.Z. Lu, H. Zhang, H.H. Fong, and N.R. Farnsworth. 2002c. Cimiracemates A-D, phenylpropanoid esters from the rhizomes of Cimicifuga racemosa. Phytochemistry 61:409-413.

Compton, J.A., A. Culham, and S.L. Jury. 1998. Reclassification of Actaea to include Cimicifuga and Souliea (Ranunculaceae): Phylogeny inferred from morphology, nrDNA ITS, and cpDNA trnL-F sequence variation. Taxon 47:593-634.

Düker, E.M., L. Kpanski, H. Jarry, and W. Wuttke. 1991. Effect of extracts from Cimicifuga racemosa on gonadotropin release in menopausal 
women and ovariectomized rats. Planta Med. $57: 420-424$.

Einbond, L.S., M. Shimizu, D. Xiao, P. Nuntanakorn, J.T. Lim, M. Suzui, C. Seter, T. Pertel, E.J. Kennelly, F. Kronenberg, and I.B. Weinstein. 2004. Growth inhibitory activity of extracts and purified components of black cohosh on human breast cancer cells. Breast Cancer Res. Treat. 83:221-231.

He, K., B. Zheng, C.H. Kim, L. Rogers, and Q. Zheng. 2000. Direct analysis and identification of triterpene glycosides by LC/MS in black cohosh, Cimicifuga racemosa, and in several commercially available black cohosh products. Planta Med. 66:635-640.

Held, R.J. 1989. Soil survey of Franklin County, Missouri. USDA-Soil Conservation Service. U.S. Govt. Printing Office, Washington, D.C.

Hornok, L. 1986. Effect of environmental factors on growth, yield and on the active principles of some spice plants. Acta Hort. 188:169-176.

Hughes, H.E. 1982. Soil survey of Greene and Lawrence Counties, Missouri. USDA-Soil Conservation Service. U.S. Govt. Printing Office, Washington, D.C.

Jarry, H., G. Harnischfeger, and E.M. Düker. 1985. Studies on the endocrine efficacy of the constituents of Cimicifuga racemosa: 2 . In vitro binding of constituents to estrogen receptors. Planta Med. 61:221-226.

Jiang, B., F. Kronenberg, M.J. Balick, and E.J. Kennelly. 2006a. Analysis of formononetin from black cohosh (Actaea racemosa). Phytomedicine 13:477-486.

Jiang, B., F. Kronenberg, P. Nuntanakorn, M.H. Qiu, and E.J. Kennelly. 2006b. Evaluation of the botanical authenticity and phytochemical profile of black cohosh products by highperformance liquid chromatography with selected ion monitoring liquid chromatography-mass spectrometry. J. Agr. Food Chem. 54:3242-3253.

Kennelly, E.J., S. Baggett, P. Nuntanakorn, A.L. Ososki, S.A. Mori, J. Duke, M. Coleton, and F. Kronenberg. 2002. Analysis of thirteen populations of black cohosh for formononetin. Phytomedicine 9:461-467.
Lehmann-Willenbrock, E. and H.H. Riedel. 1988. Klinische und endokrinologische Untersuchungen zur Therapie ovarieller Ausfallserscheinungen nach Hysterektomie under Belassung der Adnexe. Zentralbl. Gynakol. 110:611-618.

Li, W., S. Chen, D. Fabricant, C. Angerhofer, H. Fong, N. Farnsworth, and J. Fitzloff. 2002. High-performance liquid chromatographic analysis of black cohosh (Cimicifuga racemosa) constituents with in-line evaporative light scattering and photodiode array detection. Anal. Chim. Acta 471:61-75.

Li, W., Y. Sun, W. Liang, J.F. Fitzloff, and R.B. van Breemen. 2003. Identification of caffeic acid derivatives in Actaea racemosa (Cimicifuga racemosa, black cohosh) by liquid chromatography/tandem mass spectrometry. Rapid Commun. Mass Spectrom. 17:978-982.

Liu, J., J.E. Burdette, H. Xu, C. Gu, R.B. van Breemen, K.P. Bhat, N. Booth, A.I. Constantinou, J.M. Pezzuto, H.H. Fong, N.R. Farnsworth, and J.L. Bolton. 2001. Evaluation of estrogenic activity of plant extracts for the potential treatment of menopausal symptoms. J. Agr. Food Chem. 49:2472-2479.

Lloyd, J.U. and C.G. Lloyd. 1884. Drugs and medicines of North America. Vol. 1. J.U. and C.G. Lloyd, Cincinnati, Ohio.

McCoy, J., J.M. Davis, N.D. Camper, I. Khan, and A. Bharathi. 2007. Influence of rhizome propagule size on yields and triterpene glycoside concentrations of black cohosh. [Actaea racemosa L. syn Cimicifuga racemosa (L.) Nuttal]. HortScience 42:61-64.

McKenna, D.J., K. Jones, S. Humphrey, and K. Hughes. 2001. Black cohosh: Efficacy, safety, and use in clinical and preclinical applications. Altern. Ther. Health Med. 7:93-100.

Moerman, D.E. 1998. Native American ethnobotany. Timber Press, Portland, Ore.

Mudge, K.W., W. Lim, J.P. Lardner, and R.L. Beyfuss. 2004. Effects of population and age on ginsenoside content of American ginseng (Panax quinquefolium L.). Acta Hort. 629:161-166.

Panossian, A., A. Danielyan, G. Mamikonyan, and G. Wikman. 2004. Methods of phytochemical standardisation of rhizoma Cimicifugae racemosae. Phytochem. Anal. 15:100-108.
Persons, W.S. and J.M. Davis. 2005. Growing and marketing ginseng, goldenseal, \& other woodland medicinals. Bright Mountain Books, Inc., Fairview, N.C.

Pethö, A. 1987. Klimakterische Beschwerden. Umstellung einer Hormonbehandlung auf ein pflanzliches Gynäkologikum möglich? Ärzt. Praxis 38:1551-1553.

Popovich, D.G. and D.D. Kitts. 2004. Generation of ginsenosides Rg3 and Rh2 from North American ginseng. Phytochemistry 65:337344.

Popp, M., R. Schenk, and G. Abel. 2002. Cultivation of Cimicifuga racemosa (L.) Nuttal and quality of CR extract BNO 1055. Maturitas 44(Suppl. 1):S1-S7.

Rushing, J.W., R.L. Hassell, and R.J. Dufault. 2004. Drying temperatures and stage of development at harvest influence active principle in feverfew, Tanacetum parthenium L. Acta Hort. 629:167-173.

Sakurai, N., J.H. Wu, Y. Sashida, Y. Mimaki, T. Nikaido, K. Koike, H. Itokawa, and K.H. Lee. 2004. Anti-AIDS agents. Part 57: Actein, an anti-HIV principle from the rhizome of Cimicifuga racemosa (black cohosh), and the antiHIV activity of related saponins. Bioorg. Med. Chem. Lett. 14:1329-1332.

Sen, S. and P.P.C. Datta. 1986. Alkaloid quantity of some Apocynaceous leaf drugs in relation to seasons. Acta Hort. 188:177-186.

Steyermark, J.A. 1977. Flora of Missouri. The Iowa State University Press, Ames, Iowa.

Struck, D.M., M. Tegtmeier, and G. Harnischfeger. 1997. Flavones in extracts of Cimicifuga racemosa. Planta Med. 63:289-290.

Thomas, A.L., R.J. Crawford, Jr., L.J. Havermann, W.L. Applequist, B.E. Schweitzer, S.F. Woodbury, and J.S. Miller. 2006. Effect of planting depth, planting season, and fungicide treatment on establishment of black cohosh in a poorly drained soil. HortScience 41: 374-376.

Xie, J.T., S.R. Mehendale, A. Wang, A.H. Han, J.A. Wu, J. Osinski, and C.S. Yuan. 2004. American ginseng leaf: Ginsenoside analysis and hypoglycemic activity. Pharmacol. Res. 49:113-117. 